\title{
The quest for sustainable agriculture
}

\author{
PETER SIMON*
}

\begin{abstract}
Since the Brundtland Commission on Environment and Development published its report in 1983 the idea of sustainable development has become popular. Although many definitions of sustainable development have been proposed, the concept is not easily implemented in a world which believes that high rates of economic growth are essential and in which economic systems are run on the basis of money flows in a setting of private property. Environmental degradation is seen as external to the system.

The article discusses the concepts of technicism and economism as the dominant features of Western culture, meaning that all problems can be solved by technical and economic means. This is followed by an analysis of technicistic and economistic concepts of sustainability. In order to develop a concept of sustainability that is not marred by technicism and economism, key features of reformational philosophy, as represented by D.H.Th. Vollenhoven are summarized, especially concepts of time. This leads to an idea of sustainability that seeks to maintain the integrity of the kingdoms of things, plants and animals through a human culture inspired by wisdom and careful stewardship.
\end{abstract}

Keywords: Sustainable development, World Commission on Environment and Development (Brundtland Commission), rational agriculture, technicism and economism, price mechanism, determination, reformational philosophy, stewardship.

\section{Introduction}

\section{In 1987 The World Commission on Environment and Development (Brundtland Commission), defined sustainable development, as}

meeting the needs of the present without compromising the ability of future generations to meet their own needs. ${ }^{1}$

This idea has become very popular in public discourse. This popularity

* Petrus Simons has been working as an economist in Wellington New Zealand since 1972. He has had positions with the New Zealand Employers Federation, and the Bank of New Zealand. From 1988-2002 he was a consulting economist in a partnership. He is a Ph. D student at North-West University on the subject: Tilling the good earth; the impact of technicism and economism on agriculture.

1 World Commission on Environment and Development, Our common future, ('The Brundtland Report'), (Oxford University Press, Oxford, 1987), p. 43. 
notwithstanding, the definition is not easily implemented when high rates of economic growth are believed to be important. Yet, since 1987 problems of climate change, pollution, epidemics and a threatening depletion of key resources such as oil, water and phosphate have become much more widespread and urgent. The expected increase in the world's population, from six billion to nine billion by 2050 and beyond would further worsen the problems, especially if the living standards of the richest countries were to become the universal standard.

Nevertheless, optimists argue that anticipated growth would provide the means to clean up the environment and prevent further degradation. Biotechnical innovations, amongst others, might make it feasible to feed nine billion people properly. ${ }^{2}$

This article discusses, first, the concepts of technicism and economism as the predominate features of Western, now globalising, culture, second, the abstractions to which technicism and economism have given rise, third, a technicistic and economistic concept of sustainability, followed, fourth, by a brief outline of D.H.Th. Vollenhoven's ontology, especially, his view on time, in relation to sustainability, whilst a final section sketches a road towards finding 'true' sustainability.

\section{Technicism and economism}

Various philosophers have argued that Western culture bears the imprint of a strong belief in science and scientific technology. Hans Sachsse sees its beginning in the time of the Renaissance, when accurate machine tools were developed and used to advance science. ${ }^{3}$ In turn, science has fostered new technologies, which have helped to advance science. From René Descartes (1596-1650) onward philosophers have had a technicistic bent. Since his work on methods, the mathematical/technical method of problem solving has been widely adopted, i.e. break a problem down into its smallest part, solve these and then put all the partial solutions together.

Thus, reality becomes a manipulated reality, subject to a never-ending process of construction and re-construction. Descartes' view that there are two substances, a human rationally thinking one and the material substance of extension has fostered technicism through the human scientist/engineer who analyses and re-fashions the rest of the world. The rationality involved is truly instrumental rationality.

2 One such optimist is historian Paul Kennedy, Preparing for the twenty-first century, (Harper Collins, London, 1993).

3 H Sachsse, Anthropologie der Technik; ein Beitrag zur Stellung des Menschen in der Welt, (Friedrich Vierweg, Braunschweig, 1978), p. 180 ff. 
Schuurman sums it up, as follows:

Technical thinking, once dominant, is unstoppable-it refuses to acknowledge the impenetrable mysteries that most deeply characterize reality as creation. Once in gear, the tireless process of constructing and reconstructing all of reality ensues. What is there that cannot be measured, weighed, counted, and thus controlled? Reality is just one big machine or, to use more modern technology, just one huge information-processing system. ${ }^{4}$

This method of constructing and re-constructing can be found in just about all modern cultural endeavours. In Europe one has tried on a number of occasions to construct and reconstruct the political map of nation states. Biotechnology seeks to find out how genomes are constructed in order to reconstruct them to develop organisms that function more optimally. In the business sector companies and groups of companies are constructed and reconstructed.

Whenever a problem emerges, scientists will analyse it into its smallest components and, then, by means of technical innovation prepare solutions. The various partial solutions are then put together and applied, even though the effects of the application might be worse than the original problem.

If the world is seen as a scientific or technical world, that is as a world which should be transformed according to the methods of science and scientific technology, then, how can it be also seen as an economistic world, that is as one in which everything is reduced to commercial and financial values?

The answer lies in the power acquired by the modern business corporation over our society. There are few areas of life that are not colonised or overwhelmed by commercial interests (notable examples are television and other modern communications media, sports, arts, education, agriculture and food, politics). Scientific technology has become a servant of the corporation in its search for new markets and/or larger market shares in a continual competition with powerful competitors. However, one can also argue that the corporation exists in order to advance scientific technology. ${ }^{5}$ History provides abundant examples of this two-way relationship.

Since the 15 th century a symbiosis developed between emerging nation states, commerce and technology, known as mercantilism. States felt that they should be able to prevail in any contest with others. In

4 E Schuurman, The technological world picture and an ethics of responsibility, ([2002], trans. John H. Kok, (Dordt College Press, Sioux Center, 2005), p. 15.

5 Recent analyses of the corporation outline admirably how the modern corporation commercialises life, but without paying much attention to the role of science and technology in this process. See DC Korten, When corporations rule the world, (Kumarian Press, West Hartford, 1995) and J Bakan, The corporation; the pathological pursuit of profit and power, (Constable, London, 2004).

TD, 2(2), December 2006, pp. 345-367. 
order to attain such end they controlled their industries and commerce and sought to accumulate reserves of money by exporting and curtailing imports. Colonies were a key part of this system, not only as an outlet for domestic industry but also as a source of exotic and much sought after goods (sugar, spices, gold, silver). A state would stimulate technical development by fostering and protecting its industries so as to gain competitive advantages in its external commerce and pursuit of new colonies. ${ }^{6}$ Thus, the Dutch were able to capture the lucrative trade with the Baltic countries in the 17th century as well as the spice trade with the East Indies on the basis of bigger and faster ships. ${ }^{7}$

When modern nation states were established, tax payments and accounting systems were required to keep track of how their economies were performing. In a macro-economic sense William Petty (1623-1687) extended this system to the accounts of a whole nation. In his view money was the measuring rod of economic life. He reduced people to 'labour', valued in money terms as 20 years of wages and land to twenty years of rent. ${ }^{8}$ This effort would have been unthinkable without the invention of double-entry accounting by Fra Pacioli (born around 1445), which encouraged the development of economic theory as a set of equations. Tax revenue and the ability to borrow money enabled nation-states to equip armies and navies to protect and expand their commercial interests.

The advent of the Industrial Revolution marked the end of Mercantilism as a formal system of protecting and fostering industry and commerce. Instead, an all-round system of markets took shape, including markets for labour, land and money. Enterprises that were specialised in manufacturing production had to purchase land, labour and capital. Polanyi called this the 'great transformation'. ${ }^{9}$ Gradually, many industrial enterprises became very large-scale and reliant on technology to conquer new markets.

Since the Industrial Revolution, technicism and economism have become inseparable, exerting their influence particularly through the business corporation.

6 JA Schumpeter surveys these trends in: History of economic analysis II, (George Allen \& Unwin, London, 1954), pp.143-378.

7 JT Lindblad, Nederland en de Oostzee 1600-1850, in Goud uit graan; Nederland en het Oostzeegebied 1600-1850, (Waanders, Zwolle, 1998); G Milton, Nathaniel's nutmeg; how one man's courage changed the course of history, (Hodder \& Stoughton, London, 1999).

8 P Strathern, Dr Strangelove's game; a brief history of economic genius, (Penguin Books, London, 2001), pp. 11-40.

$9 \mathrm{~K}$ Polanyi, La grande transformation; aux origins politiques et économiques de notre temps, ([1944] trans. C.Malamoud, Éditions Gallimard, 1983). 
During the last twenty years consumer behaviour, especially in AngloSaxon countries, has changed from observing a budget constraint to borrowing and buying, almost regardless of income or interest charges. Banks encourage them to use credit cards to the full and to take high mortgages. The more people borrow for the purpose of purchasing real estate, the higher are the prices thereof and the safer the mortgages for the banks. Rising prices enable borrowers to increase their mortgages to finance higher spending. In a globalised economy, a growing part of consumption consists of imports from countries with abundant labour, and hence low wages, and low environmental standards. I agree with Gréau that globalisation through an elimination of import barriers under WTO is really a way of reducing the costs of labour everywhere, so as to raise profitability. ${ }^{10}$

Debt-financed consumption must rate as a major contributor to environmental degradation. Consumers in the US or Europe have little or no idea what the production of their consumption goods costs in China, India or Latin America in terms of environmental impact and human misery. In fact, the EU and the USA have been subsidising their agricultural industries to the extent that surpluses have to be dumped on world markets to the detriment of localor traditional farmers, forcing them off their land. They have no option but to work in towns at extremely low wages in order to produce consumer goods for the rich countries. However, in the rich Western countries farmers, especially those involved in intensive farming, suffer too, as witnessed, for instance, by Camille Guillou, a French farmer from Brittany who wrote a litany on the professional and personal problems experienced by industrialised poultry farmers. ${ }^{11}$

The link between technicism and economism is seen too in a reduction of time to mechanical time. ${ }^{12}$ Speed, measured in units of clock time, is essential in battles for commercial supremacy. Technicism and economism may, therefore, also be considered as ways of speeding up processes in clock time.

Thus, industrial agriculture has been under constant pressure to produce more by raising its productivity. Since most of a farmer's costs are fixed, higher production results in higher net income. Unfortunately, since all farmers are doing this simultaneously, increasingly on a world-wide scale, prices tend to fall, given that demand for food increases but slowly. This has led to the development of highly intensive industrialised agriculture in all parts of the world. Inputs include

10 J-L Gréau, L'Avenir du capitalisme, (Gallimard, Paris, 2005), pp. 75-124.

11 Camille Guillou, Les Saigneurs de la Terre, (Albin Michel, Paris, 1997).

12 A Vlot, Tijd voor de eeuwigheid: de techniek staat voor iets, (De Vuurbaak, Barneveld, 2002), has analysed this phenomenon.

TD, 2(2), December 2006, pp. 345-367. 
chemical fertilisers and sprays that tend to lessen the quality of soil and water as well as anti-biotics and growth hormones to speed up natural growth. Plants as well as animals are bred so as to fit in with the requirements of mechanical processing. Indeed, farm animals have become completely dependent on the technology and science applied by agriculture.

The world has been put into the mould of a highly destructive technological/economic system.

\title{
2. Abstraction
}

The discipline of economics arose during the 17th and 18th centuries, along with the development of natural science. Rationalism focussed on an examination of cause and effect. 'Nature' was seen as the only authority. Although both Quesnay and Adam Smith believed that there was a natural tendency in the world towards a pre-established natural harmony, they differed in terms of their interpretation of 'natural'. For Quesnay nature was a biological organism, which could suffer from sickness. For Adam Smith it was a mechanical system. Anyhow, both thinkers believed that the economic system of supply and demand would work best, that is would produce a harmony of economic interests, in a laissez-faire system. ${ }^{13}$ During the 19 th century Karl Marx introduced another interpretation of natural law by arguing that:

\begin{abstract}
At the basis of all historical change there is the logic of an autonomous gradual economic development, of progress in the methods and the organization of production. ${ }^{14}$
\end{abstract}

One may either accept the results of this process or withstand them, at the risk of revolution. Modern neo-liberalism represents a similar deterministic view of historic economic development. Unless one accepts free trade and private property and limits government involvement to balanced budgets and processes to ensure that business can thrive, one is bound to have sub-optimal economic outcomes.

No matter how the natural order is conceived, it involves a set of abstractions. One abstracts from the human interactions between people and business and between people and nature. In neo-classical theory one also abstracts from technical change.

However, if economic action is understood as part of an abstract natural system, governed by an automatically working price system, one removes the responsibility of human actors for their economic actions,

13 See E Heimann, History of economic doctrines; an introduction to economic theory, ([1945] Oxford University Press, New York, 1972), pp.16-19.

14 Ibid., p.142. 
except in the sense of managing their balance sheet to the satisfaction of the providers of capital. The human suffering associated with the Industrial Revolution owes much to this theoretical removal of human responsibility. It was a revolution as the combination of science, technology and capital transformed societies. E. Hanzig-Bätzing and $\mathrm{W}$. Bätzing argue that ten independent developments from the $14^{\text {th }}$ to the $19^{\text {th }}$ century came together in this revolution, namely:

- A strong increase in agricultural productivity;

- Removing people from the land (enclosures);

- The emergence of a financial system;

- Specialisation of labour;

- A bureaucratic absolutist state, with independent police, army and judiciary;

- Abstract notions of human dignity, freedom, fraternity and equality;

- A protestant work ethic (Max Weber);

- Disciplined people (work houses, military);

- Modern science;

- Energy (coal or steam). ${ }^{15}$

Although I agree that these ten factors do explain the dynamic changes brought about by the first and following industrial revolutions, I am not convinced that they are truly independent. In each of the ten developments there is a strong scientific/technical element. What is true, however, is that in this process of general technicisation, nature has become a resource or a piece of material that can be formed and transformed for human ends. ${ }^{16}$ This fits in with the authors' general thesis that the present world is characterised by a limitless delusion that everything can be made and remade, a delusion which, paradoxically, also affects humankind. ${ }^{17}$

Another way of putting this is suggested by Goethe's Faust, part II, when Mephistopheles suggests to the Emperor that he might fill his empty state coffers by issuing paper money, secured against all the (unknown) treasures that people have hidden in the ground. ${ }^{18}$ For treasures we might refer to oil, gold, copper, iron ore, uranium, plants, animals, life-forms and the like.

The overarching significance of technicism has been elaborated in many

15 E Hanzig-Bätzing and W Bätzing, Entgrenzte Welten; die Verdrängung des Menschen durch Globalisierung von Fortschritt und Freiheit, (Rotpunktverlag, Zürich, 2005), pp. 30-38.

16 Ibid., pp. 50,51.

17 Ibid., p. 11.

18 JW von Goethe, Faust II, ([1832], trans. David Luke, Oxford University Press, Oxford, 1994), Par. 4930. 
ways by Egbert Schuurman. He has drawn attention to four key abstractions in our world picture, namely:

- One function out of a pattern of functions;

- Within this functional framework one abstracts from concrete entities;

- From visible observable reality to concentrate on the laws applying to selected fields; and

- From private interests. ${ }^{19}$

I suggest that we should also add the monetary abstraction as touched upon above, even though it is actually part of the economic function. As a technical object money is destined to function as an economic instrument. It is made from ink, electronic signals and paper and can be multiplied at will and spent in whatever way seems lucrative, regardless of environmental or human consequences.

A few notes on each to highlight technicism and economism may suffice.

\subsection{Functional abstraction}

Policy-makers believe that they should encourage economic growth by promoting technical innovation. They also believe that they should encourage people to save by combating inflation (raising interest rates) or suitable tax rates so that the economy is able to accumulate capital sufficient to raise productivity and output. The government itself will invest in infrastructure as well as in education and health to ensure that there are enough healthy workers, scientists and technologists. Thus, in modern societies the scientific, technical and economic functions loom large. One does not inquire too deeply how an over-emphasis on these functions affects other important functions such as the lingual, social, aesthetic and juridical ones.

\subsection{Monetary abstraction}

During the early Middle Ages and lasting until the Industrial Revolution, the Church had a battle with merchants and commerce, especially by a prohibition of lending money at interest. This was founded on Scripture and seen as buttressed by Aristotle's saying that money does not beget money. ${ }^{20}$ Eventually, the merchants won this battle. Economic life became very much an autonomous way of life ('business is business').

19 E Schuurman, Faith and hope in technology, ([1998], trans. John Vriend, Clements Publishing, Toronto, 2003) pp. 96 ff.

20 B. Grandia, Zeven maal zeven; over sabbatjaar en jubeljaar als Gods bevrijdende economie, (Ten Have, Baarn, 1998), pp. 186-211. 
Money rules in the business world. All transactions involving money are recorded in profit and loss accounts and balance sheets. Everything else affected by these transactions is external to profit-making and, therefore, not accounted for.

The importance of the rate of interest illustrates the pervasive nature of monetary abstraction. At present, monetary authorities are only able to influence short-term interest rates. They tend to do so without worrying about the consequences, other than the effect on the rate of inflation and often the need to prevent capital flight. Consequently, interest rates adjusted for expected inflation have become positive and as such are often higher than the growth rate of real Gross Domestic Product (GDP), leading to an explosion of debt.

Yet, the rate of interest is not a price like the price of goods, such as, for example, butter. It is a price to be paid for the future (a sum of capital) from incomes earned in the present. In practice, this is only possible if the present system keeps expanding. A business which hires capital at interest to process wool produced by farmers will be able to pay the wool and wages if the workers and the farmers buy the wool. In order to earn the extra income to pay the interest, there should be other people employed by other firms that want to buy woollen garments.

More importantly, the circulation of money does not extend to people who, for whatever reason, have no access to monetary sources of income. In all parts of the world millions of people depend on subsistence farming, or industry (such as fishing), barter, government or foreign donors and other forms of charity.

\subsection{Abstraction from concrete people and entities}

As policy is directed and informed by the narrative of economic growth, its abstract functional nature is projected onto reality where it affects the actors in the real world and, therefore, the kingdoms of things, plants, animals, people and the webs of relationships between them. Although on-going exponential economic growth may inflict irreversible and irreparable damage on the natural world, there is no systematic monitoring of such effects. Some argue that as long as the system provides employment and income, this is not so important. Indeed, ecological damage should be considered an incentive for innovation and investment.

Since environmentalists concentrate on the harmful environmental effects of the current economic monetary system, their policy-making ideas emphasise regulations and standards. They seek to broaden the nation's accounting base by including environmental stocks and flows.

In practice, as concerns mount about the state of the environment,

TD, 2(2), December 2006, pp. 345-367. 
government policy will incorporate elements from both the functional and the regulatory approach. Schemes are being set up to enable trading in pollution quota in the hope that the costs of pollution so imposed will stimulate the search for cleaner technologies, i.e. pollution can make money. At the same time, new developments, such as irrigation schemes and the construction of roads, will require resource consents. They tend to spark legal battles between business corporations and 'greens'. In fact, a legal function is substituted for an economic one.

If policy-making largely abstracts from that which is concrete, then, how can sustainability in the sense of the Brundtland definition be ensured? Since the definition is in terms of concrete things such as needs and generations of people, an approach which abstracts from what is concrete, cannot be very informative.

Present generations live in an environment that is increasingly dominated by corporate powers that seek to turn wants into needs, suggesting that we should try to live life to the full by, amongst other things, consuming as much as we are able to.

\subsection{The Abstraction of objectivity}

Since government policy is by nature prescriptive due to the state being a judicially qualified entity, it easily falls under the spell of the scientific abstraction of objectivity. The laws of economics (the price mechanism), usually formulated by neo-classical mechanistic economic theory, are easily adopted by politicians. They are promised optimal economic welfare if they allow all markets to come into equilibrium by giving free rein to the interplay of demand and supply, similar to the equilibrium that prevails in the realm of heavenly bodies under the working of gravity. It is rarely appreciated that in this way they impose an abstraction on a real world dominated by concrete powerful entities such as business corporations.

\subsection{Abstraction from private interests}

The prevalence of these corporations is such that the abstraction of private interests i.e. that scientists are only interested in seeking the truth is honoured more in the breach than in the observance, because they are supposed to serve the interests of their employers. Should universities be dependent on corporate money to finance their research, then, this abstraction becomes pretty well meaningless.

The conclusion must be that an approach to sustainability that features a crisp definition such as the one proposed by Brundtland has little chance of success. Given the power of the current ideology of growth other definitions would fare little better. 


\section{Technicistic and economistic sustainability}

The concept of sustainability tends to be defined in terms of the Brundtland definition, as quoted above. Being a definition focussed on people, i.e. on current and future generations and their needs, it is very anthropocentric. By being silent about the kingdoms of things, plants and animals, it suggests that these exist, merely to serve human needs. In a sense this is true. As humans we are called upon to open up the meaning of these kingdoms, but without impairing their integrity and their cohesiveness. Under Brundtland, however, we could still have large heaps of waste products, contaminated rivers or cows bred into milking machines, as long as future generations would be able to satisfy their needs, whatever these might be. To overcome some of these problems, Dauncey and Mazza have proposed an amended definition, as follows:

Sustainable development meets the needs of the present generation of humans and other species without compromising the ability of future generations to meet their own needs, while restoring local and global ecosystems. ${ }^{21}$

This alteration makes it even more important to know what needs are and over what time frame local and global ecosystems should be restored and how. Would a cow bred into a giant udder be allowed under this definition? ${ }^{22}$ One could argue that her need of food, water and medicine might be satisfied and that she would have an enhanced ability to meet the needs of people. Whether it would be right to breed such an animal is another matter altogether. Such a cow would be completely dependent on human technology to survive and to deliver calves, being bred technicistically for material profit (economism).

Therefore, the amended definition could be interpreted and acted upon in terms of technicism and economism. Indeed, since, as argued above, our world is subject to technicism and economism, we should suspect that what is known or advocated as sustainability might be a reflection of these two cultural powers.

\subsection{Dialectics}

One hint in this respect is that there are mainstream and dissident voices about sustainability. The former would argue that economic growth is called for to provide the means (tax revenue, surplus income) to clean up the environment. This is expressed, for instance, in the Kuznets curve. It has two axes. The vertical one indicates the degree of environmental damage, whilst the horizontal one sets out

21 G Dauncey and P Mazza, Stormy weather: 101 solutions to global climate change, (New Society Publishers, Gabriola Island, Canada, 2001), p.195.

22 C Tudge, So shall we reap, (Allen Lane, Penguin Books, 2003), p. 257.

TD, 2(2), December 2006, pp. 345-367. 
income. The lower the income, the greater the environmental damage caused by production and consumption. Those who accept this curve as a normative statement, argue that as economic growth proceeds, means become available to clean up the environment. However, the damage has been caused by the same process of production and consumption. China and India are low-income countries with a large surplus of labour. They appear to care little for their environment, for the preservation of their natural resources or for the health of their people. They spend a great deal of money improving technical and scientific education. In addition, China and other Asian countries have been building up some of the world's largest foreign exchange reserves. When would they have sufficient to start cleaning up their pollution, waste of water and soil, improve health provision etc.? The richer they become the more wasteful they become, as they simply adopt American or European standards of living. Food will increasingly be imported.

As noted, there is (growing) opposition to practices that bring about environmental degradation. With regard to agriculture, the division is between those favouring industrial agriculture and those who wish to strive for organic or biological farming. The various streams advocating biological farming all recognise that modern standard industrial agricultural practices, which rely on chemical fertilisers and sprays, as well as on botanical and zoological re-engineering, are unsatisfactory. Often one calls for a return to nature, to organic practices, to going slow and even to animistic type rituals. In turn, such calls may result in 'official' practices being adjusted, for instance, to integrated pest management. However, prevailing attitudes in the scientific/research community are that environmental problems as well as problems of food security for a growing world population should be solved on the basis of serious science that is capable of being translated into scientific technology. Currently, that means a continued development of biotechnology in conjunction with information technology. Truly biological agriculture gets very little research attention by comparison. Biological agriculture is seen either as a hobby or as a new field for biotechnology. This can only mean that the dialectic between industrial and biological agriculture will remain active. It is unlikely to become to a satisfactory solution. Indeed, when biological agricultural ventures do well, corporations move in to re-capture markets they could lose. ${ }^{23}$

Alternative ways of practising agriculture are not easily implemented in a world that has been following a different road for so long. This is seen also in a number of modern institutions that make the achievement of true sustainability exceedingly difficult. They appear to be

23 A Baddock, "Editorial" in Organic New Zealand, 65 (4), (July/August 2006, p. 5). 
key elements in technicistic and economistic practices. Hence, a brief review may be in order.

\subsection{Modern mercantilism}

Despite growing globalisation, representing a greater intertwinement of production, logistics, financial and consumer networks world-wide, mercantilism has remained a key policy. As the rules of the World Trade Organisation (WTO) require member countries to remove import protection, exposing them to vigorous competition, many governments promote exports. Countries such as Brazil and New Zealand aim their research and technology at improving the efficiency and quality of their export sectors. Bio- and information-technology will be deployed to this end.

At the same time, they become major importers of processed foods. Such imports put pressure on the export sector to improve productivity. Efforts to make agriculture more sustainable, take place within this framework. Issues relating to social rural development, the overall ecology, bio-diversity and animal welfare issues take second place. Part of production may be put on a biological footing, whilst technicistic practices such as artificial insemination with long-term risks of genetic erosion continue. Sometimes, biological production uses soils that have not yet been restored to health after long years of treatment with chemical fertilisers. ${ }^{24}$

\subsection{Private property and money}

Without the institution of private property, modern globalisation would be very different if not outright impossible. Business corporations operate globally in search of profits from which dividends can be paid to shareholders, salaries and wages to executives and workers, interest to bankers and as little tax as possible to governments. Since the late 1970s neo-liberalism as ideology was used to justify this pursuit. John Locke's labour theory of property has been invoked in defence of private property as that part of the world that has been improved by one's labour and which should be defended by the state. The state itself should divest itself of any property that may be looked after and developed by private interests, because it would never have the same drive and commitment as those who need to make a profit from their own property. ${ }^{25}$

24 G Harvey, We want real food, (Constable, London, 2006).

25 A good overview is given by U Duchrow \& FJ Hinkelammert, Property for people, not for profit: alternatives to the global tyranny of capital, (Trans. E. Griffiths et al., Zed Books, London, 2004).

TD, 2(2), December 2006, pp. 345-367. 
Historically, John Locke (1632-1704) lived during the time of the British agricultural improvers. He even personally had vested interests in land. Hence, his labour theory of property put him on the side of those who wanted to enclose the commons. ${ }^{26}$ This theory is flawed in a number of ways. First, it fails to recognise that the ability to labour is not just the result of private efforts. Without the contributions of teachers, parents, friends, neighbours and the common heritage of the traditions and knowledge of humankind, nobody would be able to gain the skills and knowledge to develop a plot of land. Second, as Henry George pointed out, plots of land, whether large or small, must be made accessible by the infrastructure as well as by the protection offered by the state through its various agencies. ${ }^{27}$ Thirdly, the produce grown or made on the land must be sold or otherwise disposed of. This requires the use not only of the infrastructure just referred to, but also of the private property owned by others such as traders, processors and distributors. Fourthly, in the modern world, the flows and transformations involved in the production process have their counterpart in money flows. Money is an institution that is common to all economic and social agents. Without a banking system, whether privately or publicly owned, economic activity, let alone capital investment, would be constrained to a very low level.

\subsection{Externalities}

The emphasis on private property, in conjunction with the modern banking and monetary system, means that anything not denominated in money falls outside the production and consumption system. A factory might pollute the water and the soil on the privately owned plot of land on which it is located, but its accounts would not show such things. Nor would the prices charged include the costs of such pollution.

\subsection{The price mechanism}

As long as prices are set as units of money (currency) per unit of a good or service, the so-called 'price mechanism' can only ensure equilibrium between demand and supply in markets that are part of the monetary system. In recent years, the Kyoto-Protocol provides for an extension of this system to trade in pollution rights. Firms get a quota of pollution rights. If they pollute more than they should, they are able to buy credits from those who pollute less. This should provide an incentive for the implementation of a cleaner production system.

26 N Wood, John Locke and agrarian capitalism, (University of California Press, 1984).

27 AW Madsen, ed., Henry George's Progress and Poverty, (The Hogarth Press, London, 1953 (1879)). 
In a future round the quotas are scheduled for reduction. Eventually, it is hoped, pollution would cease. In terms of the Kyoto Protocol, the quotas are set on the basis of the emissions recorded in 1990, with the goal being to reduce new emissions to less than 5 per cent of the 1990 baseline by 2012. Since the problem of greenhouse gas emissions has been developing since the 1800s the target is exceedingly modest. Its attainment would have little impact on the total volume emitted and its effects on the world's climate.

In fact, under the impact of rising oil prices, modern machinery has become much more energy-efficient, emitting less greenhouse gases. However, because of a strong increase in demand and production, the use of fossil energy and the emissions of greenhouse gases have been increasing.

\subsection{Time}

As noted above business reduces time to mechanical time. The more we can produce per unit of mechanical time, the higher our productivity. This is achieved more likely by automated machinery than by human labour. The use of machinery has allowed a very refined division of 'labour' across countries and continents, with a concomitant increase in transport flows. Since suppliers of industrialised agriculture have set up large-scale specialised production processes for fertilisers, sprays, implements, medicines and of throughput of farm animals and supplies, agriculture too has become dependent on major transport flows across the globe. To play their role in this system agricultural practices have also become mechanised. Animals and plants have been bred so as to fit in with this high production per unit of time model.

\subsection{Rational agriculture}

Estelle Deléage has contrasted rational agriculture and sustainable agriculture. ${ }^{28}$ The former means that the problems caused by too high an application of chemical inputs should be resolved technically and scientifically. One should as far as possible minimise the impact of industrial agriculture on the natural environment. One seeks solutions in terms of new devices such as GPS (Ground Positioning System), new fertilisers, new pesticides and Genetically Modified Organisms (GMOs) and hopes, in the process, to maintain monetary profitability.

Thus, farmers remain part of the industrial chain from suppliers to

28 E Deléage, Paysans de la parcelle à la planète; socio-athropologie du réseau agriculture durable, (Syllepse, Paris, 2004), p. 142. 
processors, without being able to establish a truly biological agriculture (one that seeks to maintain the integrity of plants and animals by using, amongst other things, biological ways of eliminating pests). The sustainability sought by rational agriculture is a technicistic/ economistic sustainability.

\section{An ontological interlude}

Most definitions of sustainability involve a concept of time. Brundtland's refers to the needs of present and future generations. It should be possible, therefore, to look at the idea of sustainability entirely in terms of time.

In Vollenhoven's systematics, time is not an agent of change, but rather a necessary condition for change. ${ }^{29}$ Vollenhoven looks at reality as being subject to the law issued by the Creator. This subjectity has three dimensions: concrete entities (ontic determination), general functions (ontological determination) and genesis (genetic determination). Each of these dimensions is present in all that is subject to the law. Each involves a different expression of time and each contributes something special to our understanding of reality that is not given by the others.

\subsection{Entities}

We notice time by observing differences between before and after when we are dealing with concrete entities. Important in this respect is how the entities cohere and are connected to each other. In general, connectedness requires a relationship, such as friendship.

In matters economic companies and their customers cohere through the relationship of seller-buyer. This relationship has many variants. They vary from very ephemeral (somebody buys a train ticket) to very complex, as in many rhizoid structures (chains of suppliers and customers). One may compare the state of a company or industry before an investment has taken place with the state after it has been fully implemented.

In agriculture one could draw a comparison between the state of farms prior to the general use of chemical fertilisers and the one after their introduction over a period of time. What happened to the availability and quality of the food produced, the health of soil and animals?

$29 \mathrm{JH}$ Kok and A Tol (eds), D H Th Vollenhoven, Isagogè Philosophiae; Introduction to Philosophy, (Dordt College Press, Sioux Center, 2005) and A Tol, "Time and change in Vollenhoven" in Philosophia Reformata,Vereniging voor Reformatorische Wijsbegeerte, vol. 60(2), 1995, pp. 99-120. 
Studies on climate warming have shown the intricate interconnections between accumulations of greenhouse gases and their effects on climate, the world's ice cover, oceans, weather, plants and animal life. Flannery shows a clear delineation of time periods, before and after 1800 and more recently before and after $1976 .{ }^{30}$

Entities occur in the kingdoms of things (inorganic), plants, animals and people. In each there is a vast multitude of them. Moreover, in the kingdom of people, objects are designed and made from entities originating in the other three kingdoms. When we don't need them anymore, they are disposed of in the natural environment. Our technical processes of production and consumption have a major bearing on the state of the other three kingdoms. It is here that the concept of sustainability must begin. How do we relate to the other kingdoms with our technology and economics? Before we start with a process, there may be a rich diversified landscape. After we have finished it might have been transformed to a bare desert full of slag heaps.

Farming is an activity through which soils, plants, animals, technical objects and people cohere. In industrial farming this activity has become abstract and dominating, without respect for the integrity of animals, plants and landscapes. Animals and plants are manipulated through scientific technology, so that they become dependent on technology. The caring or nurturing relationship of the farmer is displaced by a scientific or technological relationship. This is argued in terms of the need to 'make money'.

\subsection{Functions}

The ontological determination concerns the modalities in which an entity presents itself. When entities are functioning they are realising modal possibilities. Everything functions in all modalities. Since they are inherent in a thing, the functions belong to its structure and the structure consists of all the analogies, both retrocipations and anticipations. ${ }^{31}$ The many functional differences cohere through the analogical structure. Time is expressed in the rhythmic periodicity of functioning, especially by observing retrocipations. Thus, the rhythm of economic life is expressed in the movements of the business cycle, in periods of growth and stagnation, of prosperity and poverty, in styles

$30 \mathrm{~T}$ Flannery, The weathermakers; the history and future impact of climate change, (The Text Publishing Company, Melbourne, 2005).

31 Functions are ordered from lower to higher and are closely related to each other by retrocipations and anticipations. A higher function refers back to lower ones. It retrocipates on them. Lower functions anticipate higher ones. Thus, the economic function retrocipates on the functions of space and biotic growth (economic space and economic growth) and anticipates the juridical and ethical functions (a just distribution of income).

TD, 2(2), December 2006, pp. 345-367. 
of fashions and in the succession of technologies (they follow a pattern of introduction, maturing and declining).

A rhythmic periodicity obtains also in the functioning of the planet earth with respect to the sun with significant consequences for the state of the climate on earth over long periods of time. ${ }^{32}$

A farm functions primarily economically, inasmuch as it seeks to produce an abundance of goods that are useful for humans and animals. There is a rhythm of sowing, nurturing and harvesting. The economic function is exercised along with the ethical (caring), juridical (ensuring every animal and staff member gets his or her rightful due), social (maintaining good contacts with neighbours, suppliers, customers), lingual (animals are properly named), technical (farm implements are working optimally), analytical (determining the right times for sowing etc.), aesthetic (farming evokes images of fruitfulness, peace, abundance) etc. I note here that the core idea of economics used here differs from the neo-classical one of allocating scarce means to satisfy human wants or needs.

In industrial farming the production process becomes dominated by the technology imposed by suppliers, processors and scientists. This disrupts the normal web of anticipations and retrocipations. This is shown in particular stark tones in intensive industrial farming (pigs, beef-lot and poultry) where the natural rhythm is replaced by a continuous system of production aided by flows of inputs from outside agriculture (feed, chemicals, energy) in order to produce maximum outputs. Accumulating heaps of waste and manure causes significant pollution of air, water and soil. In dairying, automatic milking around the clock is another case in point.

\subsection{Genesis}

In the kingdoms (things, plants, animals and people) subjects trace a life-line, so that we can distinguish past and future, earlier and later. Each kingdom imposes limits as to the type of events that are possible. Soils cannot grow, but may become drier or wetter over time, richer or poorer in mineral content. Forests may die; animals become extinct or may proliferate and become a plague. Biographies of people describe lifelines in terms of achievements, failures, views etc. Similarly, one may write company histories. Greenhouse gases, such as carbon dioxide, remain in the atmosphere over long periods, making it difficult to deal with the problem of climate warming.

In industrial farming systems the normal lifeline of animals is economistically reduced to their productive years.

32 Ibid., p. 63ff. 


\section{Towards a true concept of sustainability}

The previous section indicates that sustainability should be considered in terms of the three basic dimensions or determinations (ontic, ontological and genetic) and especially with respect to the passing of time in each of these determinations. In practice such consideration involves the systematic gathering of data, the patient modelling of processes and the preparation of human action.

\subsection{The gathering of data}

\subsubsection{Occurrence in ontic determination}

It should be possible to set up a database of what has been happening to subjects in the kingdoms of things, plants and animals in a particular area. Often we become concerned about sustainability by noticing problems such as the pollution of water, the disappearance of insects, birds and fish, or their migration to cooler latitudes, the odour of ammonia or the lack of animal welfare. Even if we are dealing with a pristine area, we need to compile an inventory of subjects, asking which subjects (things, plants, animals, people) occur in it and how these occurrences are changing over time.

Such an inventory will include entities such as farms, manufacturing plants, roads, railways, houses and other structures and how they are connected with each other and with entities in other regions.

\subsubsection{Occasions in ontological determination}

The next step is to inquire how processes and interactions are shaping the patterns identified. This will also necessitate an examination of human involvement. The investigation may discover that factories upstream are occasioning a pollution of the rivers flowing through the area. Sometimes factories or power stations in other countries may occasion flows of sulphuric acid that kills trees. Volcanoes may occasion flows of ash, fertile lava and sulphur. Farmers might occasion a run-off of nitrates into streams as they apply more nitrogen fertiliser than the soil is able to absorb.

Flannery has outlined how climate warming has been caused, in all probability, by the Industrial Revolution and the consequent need to fuel machines, houses, cars, ships etc by means of fossil fuels such as coal, oil and natural gas. ${ }^{33}$ In his view, the process may be halted by means of a series of technical steps that everybody is able to take.

33 Ibid., pp. $69 \mathrm{ff}$.

TD, 2(2), December 2006, pp. 345-367. 


\subsubsection{Lifelines in genetic determination}

As the stocktaking continues, the interaction of occurrences and occasioning will make it possible to model the lifelines of subjects. The pollution of streams may shorten the normal lifelines of fish species, causing their untimely death. Modern dairying and sheep and beef production systems require that cows are slaughtered before they are five years old.

If forestry industries cut a certain number of mature trees, the effects on the duration of the forest over a period of time can be assessed. It stands to reason that deliberate efforts to lengthen the lifelines of subjects in all kingdoms would slow down not only the rate of economic growth, but also pollution. There is wisdom in the 'slow growth' movement. Quality would become more important than quantity.

\subsection{Patient modelling}

Once the data are assembled, modelling would have to be undertaken to get a precise idea of how technical/economic transformations occasion flows and how flows are again transformed into other flows. A dairy factory will collect milk from farms for transformation into flows of milk powders, cheese, butter and casein. The flow of whey may be transformed into vodka in another plant. Of course, the dairy farms will have transformed flows of sunshine, rain and grass via cows into milk, producing flows of effluent that is stowed in ponds. The flow of milk from farms to factory will cause flows of exhaust gases. By drawing a map of all important flows, stows and transformations, it should be possible to identify those factors that would harm the future capability of the area to yield beneficial flows and those that would enhance it.

In agriculture one would have to model the current trend towards ever larger-scale farms based on manufactured inputs such as chemical fertilisers in contrast to diversified, mixed, small but self-sustaining family farms.

\subsection{Human action}

Given the database and the dynamics resulting from the modelling, office-bearers will have to judge whether existing controls are adequate or whether intervention is called for to stop or modify some or all of the processes that appear to be harmful from a longer-term perspective. They will call upon scientific advisers, study results from other areas, consult those responsible for the economicor technical transformation processes, etc. It will indeed be important that they do not act as enlightened despots. The views of all who have a stake in the future of the area will be important. 
Deléage discusses the approach to sustainability developed by groups of farmers in the Brittany area of France. ${ }^{34}$ They have been using a grid of 24 criteria to evaluate agricultural practices, divided into three groups of eight (economic, social, environmental). Technical matters are included in the economic criteria. The practical effect has been that modern industrial intensive farming practices have been rejected in favour of long-term biological farming.

I would accept this approach, but would prefer to extend it much more along the lines suggested above. There should also be ethical, juridical, technical and aesthetic criteria. Furthermore, the diagnosis could be improved by the suggested modelling based upon the three concepts of time.

Even so, the attempts of the groups as described are an impressive start towards true sustainability. Perhaps, in agriculture sustainability is easier to achieve than in other sectors. If the same approach were applied to industrial manufacturing, urban areas would have to introduce a drastically different lifestyle.

In general, it is important to start with small ecologically distinct areas where actors can support each other. Agriculture has the advantage that it involves all kingdoms in a very visible manner. It is also an activity through which a number of independent farmers exercise stewardship over large tracts of land and water. The example of Cuba shows that production of vegetables may be increased significantly on a biological basis by a better stewardship of available land. ${ }^{35}$ In order to underpin such stewardship it would be appropriate to vest the ownership of land in a fund from which farmers (and others) lease land on the basis of pre-determined criteria of stewardship. The fund should regularly consult with leaseholders as to the appropriateness of such criteria. ${ }^{36}$

\section{Conclusion}

The idea of sustainability has been conceptualised mainly in a technicistic and economistic fashion. Modern abstractions prevail. This approach results in a minimal and partial alleviation of environmental problems.

An attempt to approach true sustainability would involve drastic changes in lifestyle. However, lifelines of soils, plants and animals would be

34 Ibid., pp.144ff.

35 J Hannover, "Das Ökoparadies im Hinterhof" in Die Zeit, 17/08/06, p. 28.

36 A Granott describes such a system in his account of the Jewish National Fund in Agrarian reform and the record of Israel, (Eyre and Spottishwoode, London, 1956).

TD, 2(2), December 2006, pp. 345-367. 
extended towards their natural limits. Agriculture would cohere socially in distinct areas, with farmers being able to play a constructive role in their wider communities. Technically, agriculture would become much more a craft than an industrial practice. Economically, prevention of waste and the attainment of healthy harvests that may be sustained without environmental harm would be key criteria.

\section{Bibliography}

A Baddock, "Who is ready to ride the organic.com bubble?" Organic $N Z$, July/Aug. 2006, vol. 65/4, p. 5.

J Bakan, The corporation; the pathological pursuit of profit and power (Constable, London, 2004).

E Deléage, Paysans de la parcelle à la planète; socio-anthropologie du réseau agriculture durable (Syllepse, Paris, 2004).

G Dauncey with P Mazza, Stormy weather; 101 solutions to global climate change (New Society Publishers, Gabriola Island, 2001).

U Duchrow and F J Hinkelammert, Property for people not for profit; alternatives to the global tyranny of capital, (Zed Books, London, 2004).

T Flannery, The weathermakers; the history and future impact of climate change (The Text Publishing Company, Melbourne, 2005).

J W von Goethe, Faust II, ([1832], trans. David Luke, Oxford University Press, Oxford, 1994), Par. 4930.

B Grandia, Zeven maal zeven; over sabbatjaar en jubeljaar als God's bevrijdende economie (Ten Have, Baarn, 1998).

A Granott, Agrarian Reform and the record of Israel (Eyre \& Spottiswoode, London, 1956).

J-Luc Gréau, L'Avenir du Capitalisme (Gallimard, Paris, 2005).

C Guillou, Les Saigneurs de la Terre (Albin Michel, Paris, 1997).

E Hanzig-Bätzing and W Bätzing, Entgrenzte Welten; die Verdrängung des Menschen durch Globalisierung von Fortschritt und Freiheit (Rotpunktverlag, Zürich, 2005).

G Harvey, We want real food; why our food is deficient in minerals and nutrients-and what we can do about it (Constable, London, 2006).

J Hannover, "Das Ökoparadies im Hinterhof", Die Zeit, No. 34, 17 August 2006, p. 28.

E Heimann, History of economic doctrines (OUP, New York, 1964 (1945)). 
H George, Progress and poverty (condensed) (The Hogarth Press, London, 1953 (original published 1879)).

P Kennedy, Preparing for the Twenty-First Century (Harper Collins, London, 1993).

D C Korten, When corporations rule the world (Kumarian Press, West Hartford, 1995).

Th J Lindblad, Nederland en de Oostzee 1600-1850 in Goud uit graan: Nederland en het Oostzeegebied (Waanders, Zwolle, 1998).

G Milton, Nathaniel's nutmeg; how one man's courage changed the course of history (Hodder \&Stoughton, 1999).

K Polanyi, La grande transformation; aux origins politiques et économiques de notre temps, trans. C Malamoud (Éditions Gallimard, Paris, 1983 (1944)).

$\mathrm{H}$ Sachsse, Anthropologie der Technik, ein Beitrag zur Stellung des Menschen in der Welt (Friedrich Vierweg, Braunschweig, 1978).

$\mathrm{J}$ A Schumpeter, History of economic analysis (George Allen \& Unwin, London, 1954).

E Schuurman, Faith and hope in technology, trans. John Vriend (Clements Publishing, Toronto, 2003 (original 1998)).

E Schuurman, The technological world picture and an ethics of responsibility; struggles in the ethics of technology (Dordt College Press, Sioux Center, 2005 (original 2002)).

P Strathern, Dr Strangelove's game; a brief history of economic genius (Penguin Books, London 2002 (first printed in 2001), Sir William Petty pp. 32-40).

A Tol, Time and change in Vollenhoven, Philosophia Reformata, vol. 60 (1995), pp. 95-120 (Vereniging voor Reformatorische Wijsbegeerte, Utrecht).

C Tudge, So shall we reap (Allen Lane, London, 2003).

A Vlot, Tijd voor de eeuwigheid; de techniek staat voor iets (De Vuurbaak, Barneveld, 2002).

D H Th Vollenhoven, Isagôgè philosophiae; introduction to philosophy, eds J H Kok \& A Tol (Dordt College Press, Sioux Center, 2005).

$\mathrm{N}$ Wood, John Locke \& agrarian capitalism (University of California Press, Berkeley and Los Angeles, 1984).

World Commission on Environment and Development., Our Common Future, (The 'Brundtland Report') (Oxford University Press, Oxford, 1987). 